\section{EREM 74/4}

Journal of Environmental Research, Engineering and Management Vol. 74 / No. 4 / 2018 pp. 66-78 DOI 10.5755/j01.erem.74.4.21428 (c) Kaunas University of Technology

\section{A Comparative Review and Multi-criteria Analysis of Petroleum Refinery Wastewater Treatment Technologies}

Received 2018/08
Accepted after revision 2018/10

-

\title{
A Comparative Review and Multi-criteria Analysis of Petroleum Refinery Wastewater Treatment Technologies
}

\section{Taylor Livingston, Bassim Abbassi}

School of Engineering, University of Guelph, 50 Stone Rd E, Guelph ON, N1G 2W1, Canada

Corresponding author: babbassi@uoguelph.ca

Bassim Abbassi, School of Engineering, University of Guelph, 50 Stone Rd E, Guelph ON, N1G 2W1, Canada

The global economy's continued dependence on fossil fuels is associated with a multitude of environmental concerns, including the production of hazardous wastes in petroleum refineries. Large quantities of petroleum refinery wastewater (PRWW) are produced daily, requiring the development of appropriate treatment methods. Activated sludge biological treatment is commonly used to treat PRWW; however, this treatment method has a high sludge production, high operational time and may not be optimally suited for the variable loading conditions of refineries. Multi-criteria analysis (MCA) is a tool capable of evaluating different wastewater treatment technologies through the weighted consideration of multiple environmental and economic factors. The following methods of treating PRWW were reviewed and evaluated using a multi-criteria analysis: biodegradation, advanced oxidation processes, electrocoagulation and microbial fuel cell technology. The MCA considered removal efficiencies, sludge production, cost-benefit, process complexity and operational time of each method and was conducted under six different weighting scenarios. Advanced oxidation processes were preferred by this analysis under all six scenarios, with overall index scores (OIS) ranging from 7.84 to 8.51 out of a possible 10 points. Biodegradation of PRWW obtained was found to have the greatest overall removal efficiencies; however, the high operational time and sludge production of this method resulted in a maximum OIS of 7.59. Electrical methods, such as electrocoagulation and microbial fuel cell technology, required further improvements in removal efficiencies to be considered as a standalone treatment method. Further research into all methods, particularly microbial fuel cell technology, is recommended.

Keywords: petroleum refinery, wastewater, hazardous waste, multi-criteria analysis. 


\section{Introduction}

The global economy's continued reliance on fossil fuels is linked to multiple environmental concerns (Greenshields et al., 1987). Petroleum refineries convert crude oil into gasoline and other petroleum-based products, such as asphalts, diesel and lubricating oils. Efficiency is inherently a priority in this industrial process, with refineries operating continuously and employing a variety of processes to produce the desired end products. Refineries first separate crude oil into its different constituent products through distillation by boiling point, a process called fractional distillation (Kockmann, 2017). Each constituent may then be subjected to a series of processes to maximise value of the finished products, including the conversion of the size or shape of hydrocarbons, solvent extraction of aromatic compounds and pyrolysis cracking to produce synthetic organic compounds (Greenshields et al., 1987). Sulphur and nitrogen may be removed by stripping the liquid and the gases or liquids produced may be washed or scrubbed to remove hydrogen sulphide, mercaptans, phenols, cresols and naphthenic acids. Wastewater produced in petroleum refineries consists of cooling water and the wastewater from these industrial processes, which may contain inorganics, oil, ammonia, sulphides, mercaptans, phenols and hydrocarbons, with the highest contaminant levels found in wastewater from fluid catalytic cracking units, crude desalting units, coking units and condensers (Burks and Wagner, 1983; Greenshields et al., 1987; Li et al., 2015).

Although several refineries employ wastewater reuse processes where possible, such as the use of wastewaters from fluid catalytic cracking processes for desalting processes, complete reuse of wastewater is currently not a viable option (Burks and Wagner, 1983). The current treatment of petroleum refinery wastewater (PRWW) typically involves gravitational oil-water separation, air flotation for suspended matter removal, and activated sludge biological treatment (El-Naas et al., 2016; Li et al., 2015; Pajoumshariati et al., 2017; Wang et al., 2015). While biological treatment is typically sufficient in reducing the high concentrations of organics, the high chemical oxygen demand (COD) and high concentrations of sulphides and other contaminants present challenges for the viability of biological treatment alone (El-Naas et al., 2016; Mallick and Chakraborty, 2017). Furthermore, the variable loading conditions that are characteristic of petroleum refineries present the risk of introducing sudden, inhibitory conditions that are not conducive to successful biological degradation (Pajoumshariati et al., 2017).

The production of sludge through biological treatment of PRWW presents a further disposal problem. Schedule 1, section F of Ontario's Regulation 347 for hazardous industrial waste from non-specific sources sets limits for the content of contaminants in sludge produced through the treatment of petroleum refinery wastewater. The list of compounds that render petroleum refinery sludge as a hazardous waste product in Ontario include benzene, ethylbenzene, phenol, toluene and xylene (Government of Ontario, 2017a). Although the treatment of sludge from petroleum refineries represents a major environmental concern, this paper focuses on the treatment of PRWW.

Multiple PRWW treatment technologies are currently being studied, including biodegradation (Banerjee and Ghoshal, 2016), advanced oxidation processes (AOP) (Chen et al., 2014), electrocoagulation (Abdelwahab et al., 2009) and microbial fuel cell (MFC) technology (Guo et al., 2015). A comparative assessment of these PRWW treatment technologies requires the consideration of multiple environmental and economic factors. Multi-criteria analysis (MCA) is a decision-making tool which condenses a set of ranked criteria into an overall index score (OIS), allowing for comparative analysis of a set of alternatives (Plakas et al., 2016). The MCA has been used to differentiate between elements of wastewater treatment plant design (Benedetti et al., 2010) as well as between household (Jóźwiakowski et al., 2015), winery (Zorpas and Saranti, 2016) and tertiary wastewater treatment technologies (Plakas et al., 2016). The use of multiple scenarios which attribute different weightings for each parameter may be used to strengthen the analysis and allow for better interpretation of the results (Jóźwiakowski et al., 2015).

Therefore, the MCA is considered a suitable approach to evaluate between different methods of treating PRWW. The objective of this study was to examine 
different methods of treating PRWW and conduct the MCA to assess each for their viability as an appropriate PRWW treatment technology.

\section{Methods}

\section{Review of PRWW treatment methods}

A review of governmental regulations pertaining to PRWW effluent in Ontario, Canada, was conducted to aid in the identification of parameters for consideration in the MCA. The five parameters selected for consideration in the MCA were removal efficiencies, sludge production, costs and benefits associated with energy usage, process complexity and operational time.

Several recent studies using each of biodegradation, $A O P$, electrocoagulation and MFC to treat PRWW were reviewed with respect to the parameters set out in the MCA. For each treatment technology, an averaged value for each MCA category was calculated or discussed using the best operating conditions from each experiment. The arithmetic mean and standard deviation for each parameter were determined to provide an estimation of the overall efficiency of each treatment method for use in later analysis.

\section{Multi-criteria analysis}

For each treatment technology, a ranking index was determined using the information and values described during the review section for that technology. The methodology used to determine the ranking indices varied between categories. They are summarised in Table 1.

Within the removal efficiency category, the removal efficiencies for COD, phenols, sulphides and oil and grease were given an equal weighting of $25 \%$. Similarly, the cost-benefit category was subdivided to consider energy production (weighted at 20\%) and energy consumption (weighted at $80 \%$ ).

Weighting factors and qualitative ranked scores were determined by the authors based on previous expertise. An overall index score for each method was determined using an adapted version of the methods set out by Jóźwiakowski et al. (2015) and Plakas et al. (2016), as described by Equation 1 and the best technology was selected using Equation 2.

OIS $=\sum_{j=1}^{M} \sum_{i=1}^{N} r_{i j} * f_{i} * c_{j}$

Where: $r$ - ranking indices for each feature; $f-$ feature weighting factor; $N$ - number of features within each category; $c$ - category weighting factor; $M$ number of categories; OIS - overall index score.

$B T=\operatorname{MAX}\left(O I S_{n}\right)$

Where: $B T$ - best technology; $n$ - treatment technology $(1,2,3,4)$.

To strengthen the results of this analysis, the MCA was conducted under six scenarios which varied the weighting factors for each category. Fig. 1 details the process used to conduct the multi-criteria analysis.

\section{Table 1}

Categories considered in the MCA and methods used to determine ranking indices

\begin{tabular}{l|l|l|l}
\hline \multicolumn{1}{c|}{ Category } & \multicolumn{1}{c|}{ Type } & \multicolumn{1}{c|}{ Objective } & \multicolumn{1}{c}{ Determination of Ranking Index } \\
\hline \multicolumn{1}{c|}{1} & \multicolumn{1}{c}{2} & \multicolumn{1}{c}{3} & \multicolumn{1}{c}{4} \\
\hline Removal efficiencies & Quantitative & Maximisation & Percentages divided by 10 \\
\hline Sludge production & Qualitative & Minimisation & Ordered by performance and given a score of 1, 4, 4, 10 \\
\hline Costs and benefits & Qualitative & $\begin{array}{l}\text { Maximisation/ } \\
\text { Minimisation }\end{array}$ & $\begin{array}{l}\text { Energy production: given either 0 or 10; Energy consumption: } \\
\text { ordered by performance and given a score of 1, 1, 7, 10 }\end{array}$ \\
\hline Operational time & Qualitative & Minimisation & Ordered by performance and given a score of 1, 4, 7, 10 \\
\hline
\end{tabular}


Fig. 1

Overview of the multi-criteria analysis with weighting scenarios

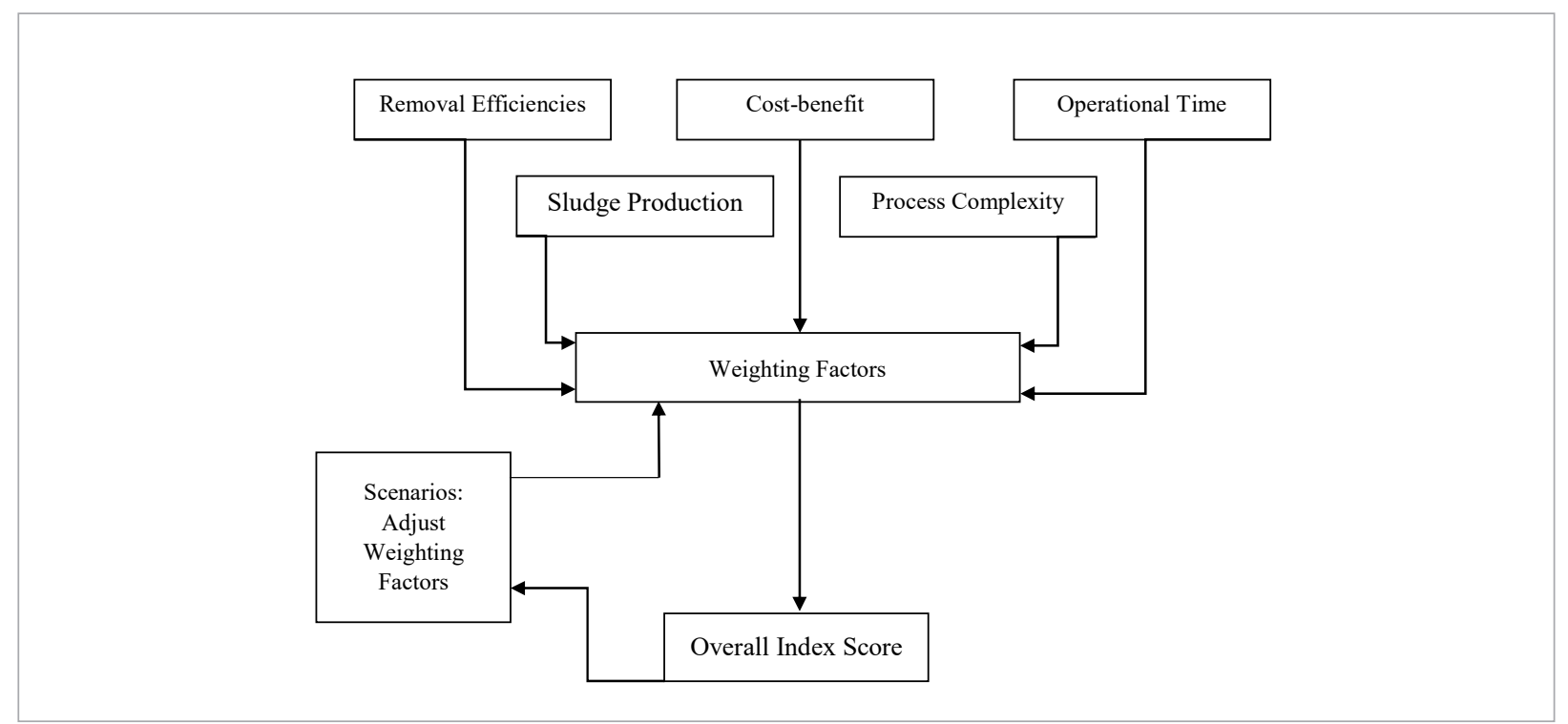

The ranking indices for each category as determined in the review sections remained constant throughout the analysis. Six weighting scenarios giving different levels of consideration to each category were used in this analysis, allowing for the calculation of six OISs for each technology using Equation 1. The OISs for each technology could then be directly compared, with the best technology being selected as that with the greatest OIS, as shown in Equation 2.

\section{Results and Discussion}

\section{Review of PRWW regulations: case study in Ontario}

To provide context to the importance of regulatory compliance for petroleum refineries, a case study of relevant regulations in Ontario was conducted. The estimation of current process water usage by petroleum refineries in Ontario provides an indicator of the total volumes of wastewater that require treatment and provides a sense of the scale needed for treatment within refineries. Table 1 provides a summary of the oil production rate and process water usage for five of Ontario's seven refineries, comparing past rates from a 1987 study to current rates (Greenshields et al., 1987). Table 2 compares process water usage data for refineries for which comparative data were available in Ontario, Canada. Where the ownership of a refinery has changed, the former company is noted in brackets. Data for current process water usage were estimated using the correction factor in Equation 3.

$$
W U_{c}=\frac{W U_{p}}{O P_{p}} \times O P_{c}
$$

Where: $W U_{c}$ - current process water usage; $W U_{p}$ previous process water usage; $O P_{p}$ - previous oil production; $O P_{c}$ - current oil production.

The results from this calculation for five Ontarian petroleum refineries are summarised in Table 2.

Table 2 provides an estimation that five petroleum refineries in Ontario currently produce a ratio of wastewater to oil production of 0.69 , which is in agreement with the literature value of 0.4-1.6 (El-Naas et al., 2016; Wang et al., 2015). This wastewater contains several compounds that require monitoring and treatment to limit exposure of the environment and humans to these compounds. Ontario Regulation 537/93 provides a listing of the maximum daily and monthly 


\section{Table 2}

Process water usage in Ontarian petroleum refineries, relative to oil production

\begin{tabular}{|c|c|c|c|c|}
\hline Refinery & $\begin{array}{l}\text { Previous Oil Production } \\
\text { Rate [m³/day] } \\
\text { (Greenshields et al., 1987) }\end{array}$ & $\begin{array}{c}\text { Previous Process } \\
\text { Water Usage [m }{ }^{3} / \text { day] } \\
\text { (Greenshields et al., 1987) }\end{array}$ & $\begin{array}{l}\text { Current Oil Production Rate } \\
\text { [m³/day] (Government of } \\
\text { Ontario, 2017b) }\end{array}$ & $\begin{array}{l}\text { Current Process } \\
\text { Water Usage }\left[\mathrm{m}^{3} / \mathrm{day}\right] \\
\quad \text { (calculated) }\end{array}$ \\
\hline 1 & 2 & 3 & 4 & 5 \\
\hline $\begin{array}{l}\text { Imperial Oil Ltd. Sarnia } \\
\text { (Esso Petroleum) }\end{array}$ & 19,078 & 18,000 & 19,900 & 18,776 \\
\hline $\begin{array}{l}\text { Petro-Canada } \\
\text { Lubricants Center }\end{array}$ & 9,539 & 13,200 & 12,900 & 17,851 \\
\hline Petro-Canada (Oakville) & 13,037 & 4,800 & 14,150 & 5,210 \\
\hline $\begin{array}{l}\text { Novacor Chemicals Ltd. } \\
\text { (Petrosar Ltd.) }\end{array}$ & 15,899 & 6,580 & 14,600 & 6,042 \\
\hline $\begin{array}{l}\text { Imperial Oil Ltd. Nanticoke } \\
\text { (Texaco Canada) }\end{array}$ & 17,489 & 6,810 & 18,600 & 7,243 \\
\hline Total [m³/day] & 75,042 & 49,340 & 80,150 & 55,121 \\
\hline
\end{tabular}

average loading for parameters of concern for each of Ontario's refineries (Government of Ontario, 2017b). Petroleum refineries are required to monitor process water and cooling water to ensure that contaminant levels adhere to regulations (Government of Ontario, 2017b).

At the federal level, the Government of Canada sets regulations regarding the maximum daily and monthly allowances for deleterious substances in petroleum refinery liquid effluent (Government of Canada, 2018). Section four of the Petroleum Refinery Liquid Effluent Regulations for Canada defines deleterious substances as oil and grease, phenols, sulphide, ammonia nitrogen, total suspended matter and any substance that could potentially alter the $\mathrm{pH}$ of water (Government of Canada, 2018). The list of deleterious substances aligns with the parameters of concern in the United States. An Environmental Protection Agency study examined removal rates for phenol, sulphide, ammonia, biological oxygen demand (BOD), total organic carbon (TOC) and oil and grease using different treatment technologies (Burks and Wagner, 1983).

For industry to ensure regulatory compliance, treatment methods must be capable of adequately reducing these hazardous substances. Where data existed, removal efficiencies for these substances were incorporated into the multi-criteria analysis.

\section{Biodegradation}

Biological treatment is commonly used in refineries to treat PRWW, following separation and flotation processes (Pajoumshariati et al., 2017). Therefore, current research into the biodegradation of PRWW is focused on optimising the design and operating conditions of bioreactors. A complication of biological treatment is the production of sludge, which is subject to regulation as a solid waste (Santo et al., 2013). Microbial populations require an adaptation period to adjust to their environment prior to degradation and can be quite sensitive to toxic loading conditions ( $\mathrm{Pa}$ joumshariati et al., 2017). Despite this, PRWW is seen as a suitable substrate for biological treatment due to its high hydrocarbon content, which microorganisms can fully degrade under the right conditions (Mallick and Chakraborty, 2017). Biological treatment systems require an inoculation period where the reactor is inoculated with bacteria-containing sludge and are often dosed with nutrients throughout operation to maintain microbial populations (Mallick and Chakraborty, 2017). One important parameter for biological treatment is the hydraulic retention time (HRT), which is a measure of wastewater treatment time (Santo et al., 2013). The main biological treatment processes of PRWW include activated sludge systems, moving bed biofilm reactors, membrane sequencing batch 
Table 3

Comparison of results from studies into biodegradation for PRWW treatment

\begin{tabular}{|c|c|c|c|c|c|c|c|c|}
\hline Reference & Description & $\begin{array}{l}\text { Hydraulic } \\
\text { Retention } \\
\text { Time [hours] }\end{array}$ & $\begin{array}{c}\text { COD } \\
\text { Removal } \\
{[\%]}\end{array}$ & $\begin{array}{c}\text { Organics } \\
\text { Removal } \\
\quad[\%]\end{array}$ & $\begin{array}{l}\text { Oil \& Grease } \\
\text { Removal } \\
\text { [\%] }\end{array}$ & $\begin{array}{l}\text { Phenols } \\
\text { Removal } \\
{[\%]}\end{array}$ & $\begin{array}{c}\text { Sulfide } \\
\text { Removal } \\
{[\%]}\end{array}$ & $\begin{array}{c}\mathrm{N}-\mathrm{NH}_{4}^{+} \\
\text {Removal } \\
{[\%]}\end{array}$ \\
\hline 1 & 2 & 3 & 4 & 5 & 6 & 7 & 8 & 9 \\
\hline $\begin{array}{l}\text { (Pajoumshariati } \\
\text { et al., 2017) }\end{array}$ & $\begin{array}{l}\text { Membrane sequencing } \\
\text { batch reactor }\end{array}$ & 8 & 80 & $\begin{array}{l}81.5 \% \mathrm{TOC} \\
\text { reduction; } \\
93.4 \% \mathrm{TPH} \\
\text { reduction }\end{array}$ & 82 & & & \\
\hline $\begin{array}{l}\text { (Schneider et } \\
\text { al., 2011) }\end{array}$ & $\begin{array}{l}\text { Moving bed biofilm } \\
\text { reactor }\end{array}$ & 6 & $69-89$ & & & 89-99 & & $45-86$ \\
\hline $\begin{array}{l}\text { (Mallick and } \\
\text { Chakraborty, } \\
\text { 2017) }\end{array}$ & $\begin{array}{l}\text { Sequential anoxic-aerobic } \\
\text { moving bed reactors; } \\
\text { used synthetic PRWW }\end{array}$ & 64 & 99.9 & $\begin{array}{l}99.9 \% \mathrm{HC} \\
\text { reduction }\end{array}$ & & 100 & 100 & 100 \\
\hline $\begin{array}{l}\text { (Banerjee and } \\
\text { Ghoshal, 2016) }\end{array}$ & Fluidised bed bioreactor & 130 & 97.86 & & & 98.03 & & \\
\hline $\begin{array}{l}\text { (Santo et al., } \\
\text { 2013) }\end{array}$ & $\begin{array}{l}\text { Activated sludge system } \\
\text { with recycling }\end{array}$ & 20 & 95 & $\begin{array}{l}87 \% \text { TOC } \\
\text { reduction }\end{array}$ & & & & \\
\hline Mean & & 46 & 90 & & 82 & 97 & 100 & 83 \\
\hline $\begin{array}{l}\text { Standard } \\
\text { Deviation }\end{array}$ & & 53 & 10 & & - & 3 & - & 24 \\
\hline
\end{tabular}

reactors and fluidised bed reactors (Pajoumshariati et al., 2017; Santo et al., 2013; Schneider et al., 2011). The results from several studies which employed one of these forms of biological treatment on PRWW are summarised in Table 3.

The highest removal efficiencies were achieved at the highest HRTs, suggesting that longer contact time increases removal efficiency under any method of biological treatment. The best results were obtained using sequential anoxic-aerobic bioreactors, with nearly perfect removal efficiencies for all parameters (Mallick and Chakraborty, 2017). Overall removal efficiencies were quite high for biological treatment, although there are considerations of long operational times and high sludge production of biological treatment.

\section{Advanced oxidation processes}

Advanced oxidation processes (AOP) are a class of wastewater treatment processes that employ a combination of ultraviolet radiation, hydrogen peroxide, ozone, $\mathrm{TiO}_{2}$ photo-catalysis, photo-ferrioxalate,
Fenton and photo-Fenton processes (Estrada-Arriaga et al., 2016). The Fenton process uses $\mathrm{Fe}^{2+}$, supplied by $\mathrm{FeSO}_{4}$ and $\mathrm{H}_{2} \mathrm{O}_{2}$ to generate hydroxyl radicals, and the photo-Fenton process involves the addition of ultraviolet radiation (Yan et al., 2014). Photo-ferrioxalate reactions use ultraviolet radiation in combination with ferrioxalate $\left(\mathrm{FeC}_{2} \mathrm{O}_{4}\right)$ (Estrada-Arriaga et al., 2016). These processes generate highly reactive hydroxyl radicals $(\cdot \mathrm{OH})$ which react with the organic contaminants of PRWW to trigger successive oxidative reactions until mineralisation of the contaminants is achieved (Davarnejad et al., 2015). Studies which used AOP to treat PRWW attempted to obtain the optimal ratio of reagents, duration and ultraviolet exposure. The results from these conditions are summarised below in Table 4.

Table 4 indicates that AOP treatment times are relatively low and that these reactions were tested under acidic conditions, with an average $\mathrm{pH}$ of 5 . However, removal efficiencies for $\mathrm{COD}$ and oil and grease are low, in the range of $60-70 \%$. 


\section{Table 4}

Comparison of results from studies into AOP for PRWW treatment

\begin{tabular}{|c|c|c|c|c|c|c|c|c|}
\hline Reference & Description & $\begin{array}{l}\text { Time } \\
\text { [min] }\end{array}$ & $\mathrm{pH}$ & $\begin{array}{l}\text { COD Re- } \\
\text { moval [\%] }\end{array}$ & $\begin{array}{c}\text { Organics } \\
\text { Removal [\%] }\end{array}$ & $\begin{array}{l}\text { Oil \& Grease } \\
\text { Removal [\%] }\end{array}$ & $\begin{array}{l}\text { Phenols Re- } \\
\text { moval [\%] }\end{array}$ & $\begin{array}{c}\text { Sulphide } \\
\text { Removal [\%] }\end{array}$ \\
\hline 1 & 2 & 3 & 4 & 5 & 6 & 7 & 8 & 9 \\
\hline $\begin{array}{l}\text { (Chen et al., } \\
\text { 2014) }\end{array}$ & $\begin{array}{l}\text { Granulated activated } \\
\text { carbon with manganese } \\
\text { oxide and ozone }\end{array}$ & 80 & 6.03 & 54.6 & $\begin{array}{l}49.1 \% \text { TOC } \\
\text { reduction }\end{array}$ & & 71.2 & \\
\hline $\begin{array}{l}\text { (Estrada- } \\
\text { Arriaga et al., } \\
\text { 2016) }\end{array}$ & Photo-ferrioxalate & 120 & 5 & 84 & & & 100 & 93 \\
\hline $\begin{array}{l}\text { (Bustillo- } \\
\text { Lecompte et } \\
\text { al., 2015) }\end{array}$ & $\begin{array}{l}\text { Ultraviolet radiation, } \\
\text { hydrogen peroxide }\end{array}$ & 45 & 5.0 & & $\begin{array}{l}78.38 \% \text { TOC } \\
\text { reduction }\end{array}$ & & & \\
\hline $\begin{array}{l}\text { (Coelho et al., } \\
\text { 2006) }\end{array}$ & $\begin{array}{l}\text { Fenton followed by } \\
\text { photo-Fenton reactions }\end{array}$ & 120 & & & $\begin{array}{l}85 \% \mathrm{DOC} \\
\text { reduction }\end{array}$ & 66 & & \\
\hline $\begin{array}{l}\text { (Aljuboury et } \\
\text { al., 2015) }\end{array}$ & $\begin{array}{l}\text { Fenton's reagent and } \\
\text { photo-catalyst }\left(\mathrm{TiO}_{2}\right)\end{array}$ & 90 & 4.18 & 48 & $\begin{array}{l}64 \% \mathrm{TOC} \\
\text { reduction }\end{array}$ & & & \\
\hline Mean & & 91 & 5 & 62 & & 66 & 86 & 93 \\
\hline $\begin{array}{l}\text { Standard } \\
\text { Deviation }\end{array}$ & & 31 & 1 & 19 & & - & 20 & - \\
\hline
\end{tabular}

\section{Electrocoagulation}

Electrocoagulation is a wastewater treatment technology that uses electrical oxidation of an anode through the application of current to generate metal hydroxides, which act as coagulants, capable of removing pollutants from PRWW (El-Naas et al., 2009). Newly formed metal hydroxides form flocs which remove contaminants by adsorbing soluble organics and can then be removed via sedimentation or flotation (Abdelwahab et al., 2009). The apparatus for electrocoagulation involves two electrodes, an anode and a cathode, which are connected to a circuit which supplies voltage to the system (Bhagawan et al., 2016). The anode is termed the sacrificial anode, as it is the source of metal ions in the solution (Bhagawan et al., 2016). The most commonly used anode and cathode material is aluminum, which was found to have the best removal efficiencies, compared with iron and stainless steel (El-Naas et al., 2009). The anodic and cathodic reactions for electrocoagulation using an aluminum anode are displayed below in Equations 4 and 5, respectively.

$A l \rightarrow A l^{3+}(a q)+3 e^{-}$
$3 \mathrm{H}_{2} \mathrm{O}+3 e^{-} \rightarrow 3 \mathrm{H}_{2}(g)+3 \mathrm{OH}^{-}$

As shown in Equations 4 and 5, applied current causes the oxidation of the metal anode into metal ions, which then form metal hydroxides in the water (An et al., 2017). Concurrent reduction at the cathode produces hydrogen gas, which increases turbulence in the water, assisting with the flocculation of pollutants (El-Naas et al., 2009). Electrocoagulation produces sludge as pollutants precipitate out of the liquid, although typically in lower quantities than biological methods (Abdelwahab et al., 2009; Bhagawan et al., 2016). Increases in variables such as current density, the thickness of the anode, or the amount of metal supplied have been found to increase the removal of phenol from PRWW (Abdelwahab et al., 2009). A comparison of several studies which employed electrocoagulation to treat PRWW is summarised below in Table 5.

The operational time for this treatment technology was minimal, averaging 64 minutes. In general, removal efficiencies are acceptable, apart from COD and sulphide removals. 
Table 5

Comparison of results from studies into electrocoagulation for PRWW treatment

\begin{tabular}{|c|c|c|c|c|c|c|c|c|c|}
\hline Reference & $\begin{array}{c}\text { Anode/Cathode } \\
\text { Material }\end{array}$ & $\begin{array}{l}\text { Time } \\
\text { [min] }\end{array}$ & $\begin{array}{l}\text { Current } \\
\text { Density } \\
{\left[\mathrm{mA} / \mathrm{cm}^{2}\right]}\end{array}$ & $\begin{array}{c}\text { COD } \\
\text { Removal } \\
{[\%]}\end{array}$ & $\begin{array}{c}\text { Organics } \\
\text { Removal } \\
\quad[\%]\end{array}$ & $\begin{array}{c}\text { Oil \& } \\
\text { Grease } \\
\text { Removal } \\
{[\%]}\end{array}$ & $\begin{array}{l}\text { Phenols } \\
\text { Remov- } \\
\text { al [\%] }\end{array}$ & $\begin{array}{l}\text { Sulfide } \\
\text { Remov- } \\
\text { al [\%] }\end{array}$ & $\begin{array}{c}\mathrm{N}-\mathrm{NH}_{4}^{+} \\
\text {Removal } \\
{[\%]}\end{array}$ \\
\hline 1 & 2 & 3 & 4 & 5 & 6 & 7 & 8 & 9 & 10 \\
\hline (Yan et al., 2014) & $\begin{array}{l}\text { Graphite; addition } \\
\text { of } \mathrm{Fe} \text {, air and } \mathrm{pH} 3\end{array}$ & 60 & & 89 & & & 64.20 & & 99.5 \\
\hline $\begin{array}{l}\text { (Abdelwahab et al., } \\
\text { 2009) }\end{array}$ & Aluminum & 120 & 23.6 & 0 & $\begin{array}{l}3 \% \mathrm{BOD} \\
\text { reduction }\end{array}$ & & 92 & & \\
\hline $\begin{array}{l}\text { (Bhagawan et al., } \\
\text { 2016) }\end{array}$ & Aluminum & 20 & 16.6 & 84 & $\begin{array}{l}67 \% \text { TOC } \\
\text { reduction }\end{array}$ & 84 & 89 & & \\
\hline $\begin{array}{l}\text { (El Naas et al., 2009) } \\
\text { Lightly contaminated } \\
\text { PRWW }\end{array}$ & Aluminum & 60 & 13 & 63 & & & & 93 & \\
\hline $\begin{array}{l}\text { (El Naas et al., 2009) } \\
\text { Heavily contaminated } \\
\text { PRWW }\end{array}$ & Aluminum & 60 & 13 & 42 & & & & 24 & \\
\hline Mean & & 64 & 16.6 & 56 & & 84 & 82 & 59 & 99.5 \\
\hline Standard Deviation & & 36 & 5.0 & 36 & & - & 15 & 49 & - \\
\hline
\end{tabular}

\section{Microbial fuel cells}

The application of microbial fuel cells to treat petroleum refinery wastewater represents a new area of research with the objective of capturing the chemical energy stored in wastewater contaminants (Guo et al., 2015). MFC are an advancement of biological treatment, using the oxidative power of bacteria to oxidise organic and inorganic compounds, whilst creating current (Logan et al., 2006). The electrons from oxidised compounds flow from the anode through a conductive material towards the cathode, which may be separated by an ion permeable membrane (Logan et al., 2006; Srikanth et al., 2016). Providing external potential between the anode and cathode promotes metabolic reactions by microorganisms, such as the production of hydrogen and degradation of waste compounds (Mohanakrishna et al., 2018). The counter flow of electrons through a conductive material generates electrical current (Logan et al., 2006; Srikanth et al., 2016). MFC as a wastewater treatment do not require aeration and produce less sludge compared with other methods (Zhang et al., 2014). MFC have been studied for the treatment of municipal wastewaters and are currently being investigated as a potential technology to treat PRWW (Guo et al., 2015).

Different configurations of MFC have been studied, with important design parameters including the electrode material, selection of single or double chamber design, the use of a proton-exchange membrane and the spacing between electrodes (Zhang et al., 2014). The simplest electrode materials are graphite and carbon cloth, while platinum catalysts can be incorporated to increase the rate of reduction reactions (Logan et al., 2006). The studies reviewed used a variety of designs, operated at the laboratory scale. Two indicators of the electrical output of a MFC are power density, a measurement of the power generated relative to the anode surface area, and coulombic efficien$c y$, the ratio between the total coulombs transferred from the substrate to the anode and that which is theoretically possible (Logan et al., 2006). These parameters are included in Table 6 in addition to the removal efficiencies and operational time.

Table 6 demonstrates that MFC are capable of treating some of the hazardous compounds in PRWW. The low coulombic efficiency indicates that more studies 
Table 6

Comparison of results from studies into MFC for PRWW treatment

\begin{tabular}{|c|c|c|c|c|c|c|c|c|c|}
\hline Reference & Description & $\begin{array}{l}\text { Time } \\
\text { [hours] }\end{array}$ & $\begin{array}{c}\text { Power } \\
\text { Density } \\
{\left[\mathrm{mW} / \mathrm{m}^{2}\right]}\end{array}$ & $\begin{array}{c}\text { Coulombic } \\
\text { Efficiency } \\
{[\%]}\end{array}$ & $\begin{array}{c}\text { COD } \\
\text { Removal } \\
{[\%]}\end{array}$ & $\begin{array}{c}\text { Organics } \\
\text { Removal } \\
{[\%]}\end{array}$ & $\begin{array}{l}\text { Oil \& Grease } \\
\text { Removal [\%] }\end{array}$ & $\begin{array}{c}\text { Phenols } \\
\text { Removal } \\
{[\%]}\end{array}$ & $\begin{array}{c}\text { Sulphide } \\
\text { Removal } \\
{[\%]}\end{array}$ \\
\hline 1 & 2 & 3 & 4 & 5 & 6 & 7 & 8 & 9 & 10 \\
\hline $\begin{array}{l}\text { (Srikanth et al., } \\
\text { 2016) }\end{array}$ & $\begin{array}{l}\text { Continuous } \\
\text { mode }\end{array}$ & 16 & 225 & 2 & 84 & $\begin{array}{l}99 \% \mathrm{HC} \\
\text { reduction }\end{array}$ & 95 & 52.3 & 79.5 \\
\hline $\begin{array}{l}\text { (Zhang et al., } \\
\text { 2014) }\end{array}$ & $\begin{array}{l}\text { Spaced electrode } \\
\text { assembly }\end{array}$ & - & 255 & $6-11$ & 84 & $\begin{array}{c}92 \% \\
\text { HBOD } \\
\text { reduction }\end{array}$ & & & \\
\hline $\begin{array}{l}\text { (Guo et al., } \\
\text { 2015) }\end{array}$ & $\begin{array}{l}\text { Double chamber; } \\
\text { separated by } \\
\text { proton-exchange } \\
\text { membrane }\end{array}$ & 50 & & & 47.1 & & 65.5 & 75.5 & 87.7 \\
\hline $\begin{array}{l}\text { (Mohanakrishna } \\
\text { et al., 2018) }\end{array}$ & Single chamber & 96 & 222.5 & & 75.78 & $\begin{array}{l}92 \% \text { DRO } \\
\text { reduction }\end{array}$ & & & 35 \\
\hline Mean & & 54 & 234 & 5 & 73 & & 80 & 63.9 & 67 \\
\hline $\begin{array}{l}\text { Standard } \\
\text { Deviation }\end{array}$ & & 40 & 18 & 5 & 18 & & 21 & 16.4 & 28 \\
\hline
\end{tabular}

are required for this technology to become a viable means of energy generation. The toxicity of PRWW to microorganisms makes PRWW a less desirable substrate for MFC treatment than municipal drinking water, which has been found capable of producing higher power densities (Zhang et al., 2014). However, there is potential for MFC to be used as a pre-treatment technology to improve the biodegradability of PRWW, while generating energy in the process (Guo et al., 2015). Although more research into this application is required, MFC offers a promising means of partially treating PRWW, with the added value of recovering energy from the wastewater.

\section{Multi-criteria analysis}

The averaged values and descriptors obtained through the previous treatment technology review sections enabled the development of ranking indices for the features of each technology, as summarised in Table 7. The calculated mean removal efficiencies that were used to determine the ranking indices for that category are intended to provide an overall estimation of the efficiency of each method for the purposes of this comparative review. Such values lack complete accuracy due to the low number of data points and different methodologies used within each study.

The multi-criteria analysis calculations were conducted under six different weighting scenarios. The category weighting factors used in Equation 1 for removal efficiencies, sludge production and cost-benefit were varied in each scenario. The category weighting factors for process complexity and operational time were kept constant at 10\% through all six scenarios as refinery operations generally have sufficiently great organisational capacity to render such considerations as minimal. A summary of the category weighting factors used in calculations under the six different weighting scenarios is provided in Table 8.

The multi-criteria analysis resulted in an OIS for each treatment technology for each of the six weighting scenarios set out in Table 8 . The resulting OIS are presented in Fig. 2, where a maximum OIS of 10 points was possible in this analysis.

AOP received the highest overall index score for all six category weighting scenarios, ranging from 7.84 to 8.51. Although the greatest overall removal efficiencies were obtained by biodegradation, this treatment method ranked second, with a maximum overall index score 
Table 7

Ranking indices for each technology for use in multi-criteria analysis calculations

\begin{tabular}{|c|c|c|c|c|c|}
\hline \multirow{2}{*}{ Category } & \multirow{2}{*}{ Feature } & \multicolumn{4}{|c|}{ Treatment Technology } \\
\hline & & 1 & 2 & 3 & 4 \\
\hline 1 & 2 & 3 & 4 & 5 & 6 \\
\hline \multirow[t]{4}{*}{ Removal efficiencies } & COD & 9.0 & 6.2 & 5.6 & 7.3 \\
\hline & Oil \& Grease & 8.2 & 6.6 & 8.4 & 8.0 \\
\hline & Phenols & 9.7 & 8.6 & 8.2 & 6.4 \\
\hline & Sulphides & 10.0 & 9.3 & 5.9 & 6.7 \\
\hline Sludge production & Sludge production & 1 & 10 & 4 & 4 \\
\hline \multirow[t]{2}{*}{ Cost-benefit } & Energy requirement & 10 & 7 & 1 & 1 \\
\hline & Energy production & 0 & 0 & 0 & 10 \\
\hline Process complexity & Process complexity & 10 & 7 & 4 & 1 \\
\hline Operational Time & Operational time & 1.5 & 9.7 & 9.8 & 0 \\
\hline
\end{tabular}

1 - biodegradation, 2 - AOP, 3 - electrocoagulation, 4 - MFC.

\section{Table 8}

Weighting factor given to each category under six weighting scenarios

\begin{tabular}{c|c|c|c|c|c}
\hline Scenario & Removal Efficiencies & Sludge Production & Cost-benefit & Process Complexity & Operational Time \\
\hline 1 & 2 & 3 & 4 & 5 & 6 \\
\hline 1 & 0.40 & 0.20 & 0.20 & 0.10 & 0.10 \\
\hline 2 & 0.40 & 0.30 & 0.10 & 0.10 & 0.10 \\
\hline 3 & 0.50 & 0.20 & 0.10 & 0.10 & 0.10 \\
\hline 4 & 0.50 & 0.30 & 0.00 & 0.10 & 0.10 \\
\hline 5 & 0.60 & 0.10 & 0.10 & 0.10 & 0.10 \\
\hline 6 & 0.60 & 0.20 & 0.00 & 0.10 & 0.10 \\
\hline
\end{tabular}

Fig. 2

Results of the multi-criteria analysis under six weighting scenarios

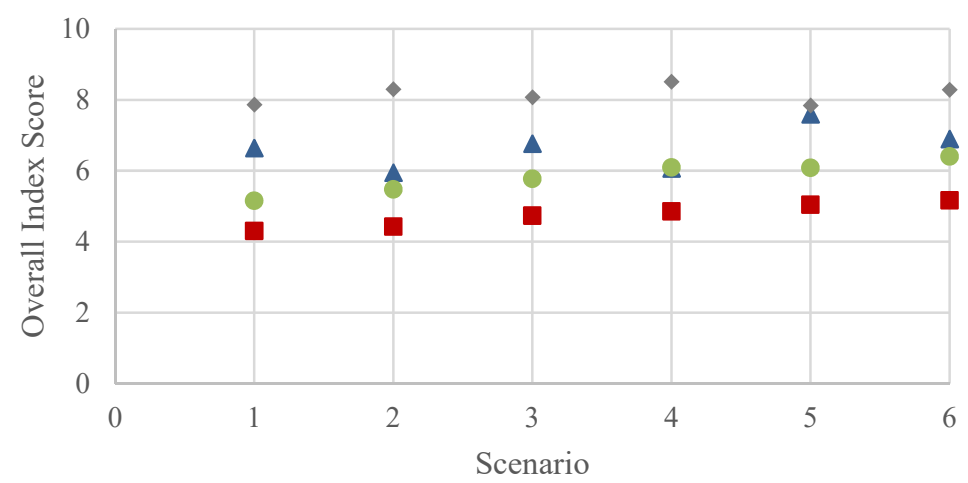

$\Delta$ Biodegradation

$\bullet \mathrm{AOP}$

- Electrocoagulation

-MFC 


\section{Table 9}

Assessment of preferred treatment technology within each category considered by the MCA

\begin{tabular}{c|c|l}
\hline $\begin{array}{c}\text { Ratio of Category Weighting } \\
\text { Factors (1:2:3:4:5) }\end{array}$ & $\begin{array}{c}\text { Preferred Treatment } \\
\text { Technology }\end{array}$ & $\begin{array}{c}\text { Treatment Technologies Ordered from } \\
\text { Highest to Lowest OIS }\end{array}$ \\
\hline 1 & 2 & 3 \\
\hline $1: 1: 1: 1: 1$ & AOP & AOP, biodegradation, electrocoagulation, MFC \\
\hline $1: 0: 0: 0: 0$ & biodegradation & biodegradation, AOP, MFC, electrocoagulation \\
\hline $0: 1: 0: 0: 0$ & AOP & AOP, MFC/electrocoagulation, biodegradation \\
\hline $0: 0: 1: 0: 0$ & biodegradation & biodegradation, AOP, MFC, electrocoagulation \\
\hline $0: 0: 0: 1: 0$ & biodegradation & biodegradation, AOP, electrocoagulation, MFC \\
\hline $0: 0: 0: 0: 1$ & electrocoagulation & electrocoagulation, AOP, biodegradation, MFC \\
\hline
\end{tabular}

1 - removal efficiencies, 2 - sludge production, 3 - cost-benefit, 4 - process complexity, 5 - operational time.

of 7.59. This discrepancy may be attributed to the high retention time and sludge production associated with biological methods of treatment. Electrocoagulation and MFC received maximum overall index scores of 6.4 and 5.16 , respectively. Table 9 provides insight into the determinations made by the multi-criteria analysis through examination of which treatment technologies performed the greatest within each of the categories.

As the results of Table 9 demonstrate, AOP received the highest OIS under every scenario because it performed well in every category considered by the MCA. Biological treatment technologies may be deemed the most suitable treatment technology for PRWW if only removal efficiencies were considered. However, the consideration of multiple criteria demonstrates that the low ranking indices for the undesirable characteristics of biodegradation, such as high operational time and sludge production make it the less preferable PRWW treatment technology compared with AOP.

\section{Conclusions}

The petroleum refinery industry requires research into new methods of treating refinery wastewater to ensure compliance with regulations. Four different methods of treating refinery wastewater were reviewed: biodegradation, $A O P$, electrocoagulation and
MFC. Each method of treatment was reviewed with respect to five categories: removal efficiencies, sludge production, energy requirements and production, process complexity and operational time. For each treatment method, each feature was given a ranking index and an overall index score was calculated using a multi-criteria analysis under six different weighting scenarios.

MCA with a scenario analysis proved to be a robust method to evaluate the relative merits of different PRWW treatment technologies. Through this assessment, AOP received the highest overall index scores for each of the six scenarios, up to a maximum of 8.51 out of 10 . The greatest overall removal efficiencies were found for biodegradation; however, considerations of the high operational time and sludge production characteristic of biological treatment reduced the overall index score.

Opportunities exist within each treatment method for future research efforts to make improvements in sludge production, removal efficiencies or other parameters of concern. The application of MFC for PRWW treatment should be subject to further research, as concurrent energy production is a desirable co-benefit of treatment that may warrant further study. Further research to improve all methods of treatment is recommended to improve efficiencies of PRWW treatment for the petroleum refinery industry. 


\section{References}

Abdelwahab, O., Amin N. K. and El-Ashtoukhy E. S. Z. (2009). Electrochemical removal of phenol from oil refinery wastewater. Journal of Hazardous Materials, 163, 711-716. https://doi. org/10.1016/j.jhazmat.2008.07.016

Aljuboury, D. a. d. A., Palaniandy, P., Aziz, H. B. A. and Feroz, S. (2015). Treatment of petroleum wastewater using combination of solar photo-two catalyst TiO2 and photo-Fenton process. Biochemical Pharmacology, 3, 1117-1124. https://doi. org/10.1016/j.jece.2015.04.012

An, C., Huang, G., Yao, Y. and Zhao S. (2017). Emerging usage of electrocoagulation technology for oil removal from wastewater: a review. Science of the Total Environment, 579, 537-556. https://doi.org/10.1016/j.scitotenv.2016.11.062

Banerjee, A. and Ghoshal, A. K. (2016). Biodegradation of real petroleum wastewater by immobilized hyper phenol-tolerant strains of Bacillus cereus in a fluidized bed bioreactor. 3 Biotech, 6(137). https://doi.org/10.1007/s13205-016-0447-1

Benedetti, L., De-Baets, B., Nopens, I. and Vanrolleghem, P. A. (2010). Multi-criteria analysis of wastewater treatment plant design and control scenarios under uncertainty. Environmental Modelling \& Software, 25, 616-621. https://doi.org/10.1016/j. envsoft.2009.06.003

Bhagawan, D., Poodari, S., Golla, S., Himabindu, V. and Vidyavathi, S. (2016). Treatment of the petroleum refinery wastewater using combined electrochemical methods. Desalination and Water Treatment, 57, 3387-3394. https://doi. org/10.1080/19443994.2014.987175

Burks, S. L. and Wagner, J. (1983). Characterization and Treatment of Aqueous Wastes and Residue from Petroleum Refineries Project Summary. Ada, OK: United States Environmental Protection Agency.

Bustillo-Lecompte, C. F., Knight, M. and Mehrvar, M. (2015). Assessing the performance of UV/H2O2 as a pretreatment process in TOC removal of an actual petroleum refinery wastewater and its inhibitory effects on activated sludge. The Canadian Journal of Chemical Engineering, 93, 798-807. https://doi. org/10.1002/cjce.22180

Chen, C., Wei, L., Guo, X., Guo, S. and Yan, G. (2014). Investigation of heavy oil refinery wastewater treatment by integrated ozone and activated carbon-supported manganese oxides. Fuel Processing Technology, 124, 165-173. https://doi.org/10.1016/j. fuproc.2014.02.024

Coelho, A., Castro, A. V., Dezotti, M. and Sant' Anna Jr., G. (2006). Treatment of petroleum refinery sourwater by advanced oxida- tion processes. Journal of Hazardous Materials, 137, 178-184. https://doi.org/10.1016/j.jhazmat.2006.01.051

Davarnejad, R., Pirhadi, M., Mohammadi, M. and Arpanahzadeh, S. (2015). Numerical analysis of petroleum refinery wastewater treatment using electro-Fenton process. Chemical Product \& Process Modelling, 10(1), 11-16. https://doi.org/10.1515/ cppm-2014-0020

El-Naas, M. H., Al-Zuhair, S., Al-Lobaney, A. and Makhlouf, S. (2009). Assessment of electrocoagulation for the treatment of petroleum refinery wastewater. Journal of Environmental Management, 91, 180-185. https://doi.org/10.1016/j.jenvman.2009.08.003

El-Naas, M. H., Surkatti, R. and Al-Zuhair, S. (2016). Petroleum refinery wastewater treatment: a pilot scale study. Journal of Water Process Engineering, 14, 71-76. https://doi. org/10.1016/j.jwpe.2016.10.005

Estrada-Arriaga, E. B., Zepeda-Aviles, J. A. and García-Sánchez, L. (2016). Post-treatment of real oil refinery effluent with high concentrations of phenols using photo-ferrioxalate and Fenton's reactions with membrane process step. Chemical Engineering Journal, 285, 508-516. https://doi.org/10.1016/j. cej.2015.10.030

Government of Canada. (2018). Petroleum refinery liquid effluent regulations. Retrieved from http://laws-lois.justice.gc.ca/ PDF/C.R.C.,_C._828.pdf.

Government of Ontario. (2017a). R. R. 0. 1990, Reg. 347: general - waste management. Retrieved from https://www.ontario.ca/ laws/regulation/900347?search=e+laws.

Government of Ontario. (2017b). Ontario regulations 537/93 effluent monitoring and effluent limits petroleum sector. Retrieved from https://www.ontario.ca/laws/regulation/930537.

Greenshields, J., Maynard, A., Rees, G. and Suboch, W. Ontario Ministry of the Environment Hazardous Contaminants Coordination Branch. (1987). Environmental contaminants in petroleum refinery wastewaters: an assessment of current information and a monitoring approach. Report prepared for Ontario Ministry of the Environment.

Guo, X., Zhan, Y., Chen, C., Sun, S., Zhao, L. and Guo, S. (2015). Simultaneous bioelectricity generation and biodegradability improvement of refinery wastewater using microbial fuel cell technology. Desalination and Water Treatment, 53, 2740-2745. https://doi.org/10.1080/19443994.2014.931535

Jóźwiakowski, K., Mucha, Z., Generowicz, A., Baran, S., Bielińska, J. and Wójcik, W. (2015) The use of multi-criteria analysis 
for selection of technology for a household WWTP compatible with sustainable development. Archives of Environmental Protection, 41(3). https://doi.org/10.1515/aep-2015-0033

Kockmann, A. N. (2017). History of Distillation. Reference Module in Chemistry, Molecular Sciences and Chemical Engineering, Elsevier. https://doi.org/10.1016/B978-0-12-4095472.14064-8

Li, Y., Fang, Z., He, C., Zhang, Y., Xu, C., Chung, K. H. and Shi, $Q$. (2015). Molecular characterization and transformation of dissolved organic matter in refinery wastewater from water treatment processes: characterization by Fourier transform ion cyclotron resonance mass spectrometry. Energy Fuels, 29, 6956-6963. https://doi.org/10.1021/acs.energyfuels.5b01446

Logan, B. E., Hamelers, B., Rozendal, R., Schröder, U., Keller, J., Freguia, S., Aelterman, P., Verstraete, W. and Rabaey, K. (2006). Microbial fuel cells: methodology and technology. Environmental Science \& Technology, 40(17), 5181-5192. https://doi. org/10.1021/es0605016

Mallick, S. K. and Chakraborty, S. (2017) Treatment of synthetic refinery wastewater in anoxic-aerobic sequential moving bed reactors and Sulphur recovery. Journal of Environmental Science and Health, 52(13), 1257-1268. https://doi.org/10.1080/1 0934529.2017 .1356190

Mohanakrishna, G., Abu-Reesh, I. M. and Al-Raoush, R. I. (2018). Biological anodic oxidation and cathodic reduction reactions for improved bioelectrochemical treatment of petroleum refinery wastewater. Journal of Cleaner Production, 190, 44-52. https:// doi.org/10.1016/j.jclepro.2018.04.141

Pajoumshariati, S., Zare, N. and Bonakdarpour, B. (2017). Considering membrane sequencing batch reactors for the biological treatment of petroleum refinery wastewaters. Journal of Membrane Science, 523, 542-550. https://doi.org/10.1016/j. memsci.2016.10.031

Plakas, K. V., Georgiadis, A. A. and Karabelas, A. J. (2016). Sustainability assessment of tertiary wastewater treatment tech- nologies: a multi-criteria analysis. Water Science \& Technology, 73(7), 1532-1540. https://doi.org/10.2166/wst.2015.630

Santo, C. E., Vilar, V. J. P., Bhatnagar, A., Kumar, E., Botelho, C. M. S. and Boaventura, R. A. R. (2013). Biological treatment by activated sludge of petroleum refinery wastewaters. Desalination and Water Treatment, 51, 6641-6654. https://doi.org/10.1080/ 19443994.2013.792141

Schneider, E. E., Cerqueira, A. C. F. P. and Dezotti, M. (2011). MBBR evaluation for oil refinery wastewater treatment, with post-ozonation and BAC, for wastewater reuse. Water Science \& Technology, 63(1), 143-148. https://doi.org/10.2166/ wst.2011.024

Srikanth, S., Kumar, M., Singh, D., Singh, M. P. and Das, B. P. (2016). Electro-biocatalytic treatment of petroleum refinery wastewater using microbial fuel cell (MFC) in continuous mode operation. Bioresource Technology, 221, 70-77. doi: 10.1016/ jbiortech.2016.09.034

Wang, B., Wan, Y., Zheng, G., Yang, M., Wu, S. and Hu, J. (2015). Occurrences and behaviors of naphthenic acids in a petroleum refinery wastewater treatment plant. Environmental Science \& Technology, 49(9), 5796-5804. https://doi.org/10.1021/ es505809g

Yan, L., Wang, Y., Li, J., Ma, H., Liu, H., Li, T. and Zhang, Y. (2014). Comparative study of different electrochemical methods for petroleum refinery wastewater treatment. Desalination, 341, 8793. https://doi.org/10.1016/j.desal.2014.02.037

Zhang, F., Ahn, Y. and Logan, B. E. (2014). Treating refinery wastewaters in microbial fuel cells using separator electrode assembly or spaced electrode configurations. Bioresource Technology, 152, 46-52. https://doi.org/10.1016/j.biortech.2013.10.103

Zorpas, A. A. and Saranti, A. (2016). Multi-criteria analysis of sustainable environmental clean technologies for the treatment of winery's wastewater. International Journal of Global Environmental Issues, 15(1/2), 151-168. https://doi.org/10.1504/ IJGENVI.2016.074359 